\title{
Patterns of bryophyte diversity in arable fields of Lithuania
}

\author{
Danguolè Andriušaitytė $\dot{~}^{*}$ llona Jukonienè \\ Nature Research Centre, Institute of Botany, Ľaliujų Ežerų 49, 08406 Vilnius, Lithuania
}

\section{Abstract}

The paper presents research data on bryophyte diversity in arable land throughout the territory of Lithuania. The bryoflora was analyzed regarding systematic structure and morphological forms, life-history strategies, mode of reproduction and frequency of species. Bryophyte diversity in arable fields of Lithuania was compared with that of Slovakia and the British Isles, which are positioned in different geographical regions of Europe.

A total of 97 species of bryophytes of 25 families and 48 genera were ascertained. Dominance of acrocarpous mosses and thalloid liverworts, high representation of Pottiaceae, Bryaceae, Mielichhoferiaceae and Ricciaceae families as well as Bryum, Dicranella, Pohlia and Riccia genera, wide distribution of annual shuttles and ephemeral colonists, high reproduction effort of the species (frequent sporophytes and asexual propagules) were specific features of the bryophytes of the studied habitats as a result of adaptations to regular disturbances. The distribution of species into six frequency groups seemed to be uneven. The most abundant group of species with the lowest frequency (1-3 records) covered $53.6 \%$ of all species. The group contained about $90 \%$ of all many-year potential life span species recorded in the habitat. Species with short life span were distributed quite evenly throughout frequency groups. No regionally-specific species were ascertained in the studied habitat. Most of arable-land-specific species recorded in Lithuania is distributed throughout different regions of Europe.

Keywords: mosses, hepatics, arable land, mode of reproduction, life-history strategies, frequency, Europe

\section{Introduction}

Arable land is among the most common habitats in Europe. It is a predictable environment with frequent, regular and largescale disturbances, colonized by plants that have the fastest postdisturbance regeneration [1]. Bryophyte species are adapted to regular disturbance by virtue of ephemeral lifestyles and compressed life histories [2]. Due to habitat transiency, most species use "waiting" strategy by surviving for a long time in diaspore bank [3], which is formed by sexually derived spores and asexually derived diaspores $[4,5]$. Because of their wide range of life traits, various modes of reproduction, bryophytes in arable land have been long of interest to botanists $[4,6,7]$. As a part of landscape, arable land influences the structure of European flora. Species of the habitat represent a considerable part of regional floras [8]. Bryophytes of arable land as a part of anthropogenic habitats of certain territories have been discussed in a series of works (e.g. [9-14]). Nevertheless, agricultural environments are often neglected by scientists in studies on

* Corresponding author. Email: danguolesan@gmail.com Handling Editor: Zygmunt Kącki

This is an Open Access digital version of the article distributed under the terms of the Creative Commons Attribution 3.0 License (creativecommons.org/licenses/by/3.0/), which permits redistribution, commercial and non-commercial, provided that the article is properly cited.

(c) The Author(s) 2013 Published by Polish Botanical Society species richness [15]. Although a wide range of investigations on bryophyte distribution have recently been performed in agricultural landscapes of Europe [16-18], bryophyte diversity in arable fields is still poorly known in comparison to vascular plants. Bryophytes are usually not included into common phytocoenological descriptions as they are thought to play a negligible role in agrarian habitats [19]. More exhaustive lists of bryophytes occurring in arable land are known from Britain and Ireland [2,20] and Slovakia [21,22]. First bryological investigations on anthropogenic habitats, including arable fields, of Lithuania have proved them to be rich in both common and rare species [23-26].

This paper presents the investigations on bryoflora of arable fields of Lithuania in 1998-2002 and summarizes all previous data. The main tasks are as follows: (i) to reveal the specificity of bryophytes inhabiting arable land according to the main characteristics of bryoflora (peculiarities of its systematic structure, morphological forms, mode of reproduction, life-history strategies), (ii) to evaluate the frequency of bryophyte species occurring in arable fields of Lithuania, (iii) to ascertain differences in the diversity of bryophytes recorded in arable fields of Lithuania from those in other regions of Europe.

\section{Material and methods}

\section{Study area}

Lithuania $\left(62.7\right.$ thousand $\mathrm{km}^{2}$ ) is situated on the western edge of the East European Plain. It is a part of the Baltic 
geomorphological province. Lithuania is the land of plains, variegated with hilly highlands: plains constitute $50 \%$, hilly highlands $-21 \%$, plateaus $-29 \%$ [27]. The highest elevation is 293.8 meters above sea level [28]. Farming land covers a considerable part of the total area (nearly 54\%) with arable land and grasslands accounting for 70.5\% [29]. The country's climate is relatively mild. Average temperature on the coast is $1.6^{\circ} \mathrm{C}$ in January and $17.8^{\circ} \mathrm{C}$ in July, in the eastern part $-2.1^{\circ} \mathrm{C}$ in January and $18.1^{\circ} \mathrm{C}$ in July; mean annual precipitation $-675 \mathrm{~mm}$ [30]. Lithuanian soils range from sands $(22.8 \%)$ to heavy clays (1.9\%) [31]. The majority of soils are close to neutral as a result of intensive liming in the years of 1963-1967 [32]. At the moment of the investigations cereals (60-65\%), potatoes (about $7 \%)$, rapes (5\%), beetroots (about 5\%) were most extensively cultivated in the territory. The majority of fields (90\%) covered the area up to 20 ha, more than half of them - up to 10 ha [33].

\section{Data sampling and analysis}

The investigations were carried out throughout the country (Fig. 1). This study is based on the material of 369 randomly selected fields. In each field, bryophytes were collected and registered in a $10 \times 10 \mathrm{~m}^{2}$ area. Additional species were searched in the remaining parts of the field (throughout entire small fields, up to $2 \mathrm{ha}$ ) or in several places of larger fields.

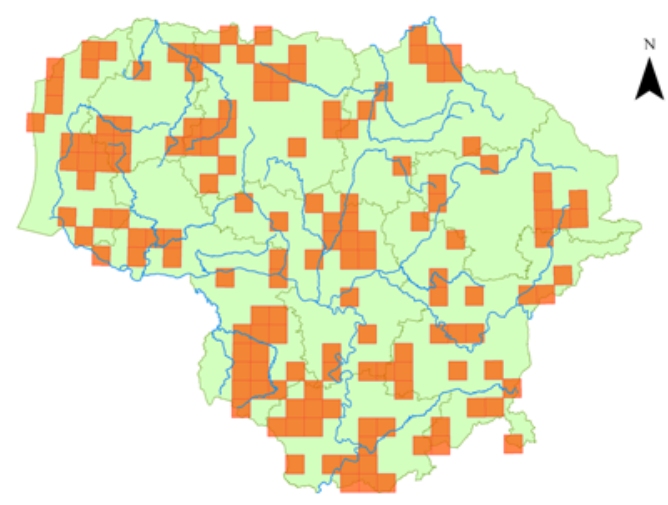

Fig. 1 Map of Lithuania showing the distribution of the studied arable fields in 151 grid squares that are arranged according to geographical coordinates with sides 6 latitude and $10^{\prime}$ longitude.

Our study was performed mainly in the fields of spring and winter cereals (71 and 117 fields, accordingly), stubbles (64 fields), clover fields (38) and fallow land up to 3 years old (79). To cover all types of habitats, the investigations were carried out throughout the year (from March till November).

Over 2000 specimens of bryophyte species were collected during the study. Voucher specimens are deposited at the Herbarium of the Institute of Botany (BILAS).

The list of species also includes some data from literature concerning the vegetation of arable fields of Lithuania [34] and bryoflora of certain territories of the country [35-37].

The classification of bryophyte species to particular lifehistory strategies according to the approach of During [38] as well as their ecological and phytogeographical characteristics and life span groups follow the ecological catalogue by Dier $\beta$ en [39]. Common data on the distribution and frequency of Lithuanian bryophytes are given according to Jukoniene $[40,41]$ and Naujalis et al. [42].
The data on bryoflora in arable fields of Lithuania were compared with the most complete available data from other territories of Europe (Slovakia and the British Isles), which occur in different biogeographic regions [43]. The British Isles (Britain and Ireland) are characterized by maritime climate, Slovakia by continental, while the climate of Lithuania ranges between continental and maritime. Lithuania is the most northern territory. To ascertain the similarity of bryofloras of the arable fields of these three territories, the Jaccard index of similarity was used [44].

The SPSS 16 statistical package was used for all data analysis. A comparison of distribution of nominal variables (types of reproductive units, proportion of life-history strategies) was performed by Chi-square tests of contingency tables. To determine the effect size, contingency coefficient $(C C)$ was examined. Differences in the frequency of the occurrence of sporophytes among monoicous and dioicous species were tested for statistical significance employing the Mann-Whitney U test. Kruskal-Wallis test was used to find out whether species of certain life span and life-history strategy were differently distributed within frequency groups and whether species of six frequency groups and of certain life span were differently distributed in groups of their recording in Lithuania and other European regions (Slovakia and the British Isles). Kendall's tau-c coefficient was used to reveal the correlation between the frequency of the occurrence of sporophytes and life span of the species. All differences were considered significant at the level $P<0.05$.

Six frequency groups of the species were distinguished according to the number of localities. Firstly, the first frequency group (very rare species) comprising species from 1-3 localities was singled out; the other five groups (rare, quite rare, frequent, very frequent and common) were established on the basis of $K$-means clustering.

The names of the species follow Grolle and Long [45] (hepatics) and Hill et al. [46] (mosses).

\section{Results}

\section{General data on bryophyte diversity, mode of reproduction and life-history} strategies

The list of bryophytes recorded in arable fields of Lithuania included 97 species (12 of these from literature reports), i.e. $21 \%$ of all bryophyte species known in Lithuania (Tab. 1).

A total of 84 species of mosses (24\% of all known in Lithuania) and 13 species of hepatics and hornworts (11\% of all known in Lithuania) were recorded. The ratio between mosses and hepatics was 6.5:1. The registered species belong to 25 families: 19 of mosses and six of hepatics representing $42 \%$ and $22 \%$ of the families of the whole Lithuanian bryoflora, accordingly. More than $40 \%$ of the species are associated with three families: Bryaceae, Pottiaceae and Mielichhoferiaceae. Eight dominant families (Pottiaceae, Bryaceae, Mielichhoferiaceae, Ricciaceae, Dicranaceae, Brachytheciaceae, Polytrichaceae and Ditrichaceae), i.e. $30 \%$ of all families, include $70 \%$ of all registered species, whereas 17 families share the remaining $30 \%, 10$ of these being represented by one species.

The recorded species represent 48 genera of bryophytes (seven of hepatics and hornworts and 41 of mosses, i.e. $12 \%$ and $17 \%$ of the whole Lithuanian bryoflora, accordingly). The richest in species was the Bryum genus (14 species). 
Tab. 1 List of bryophytes recorded in arable fields of Lithuania.

\begin{tabular}{|c|c|c|c|c|}
\hline \multirow[b]{2}{*}{ Family } & \multirow[b]{2}{*}{ Species } & \multicolumn{3}{|c|}{ Number of records } \\
\hline & & Total & With sporophytes & With asexual propagules \\
\hline 1 & 2 & 3 & 4 & 5 \\
\hline \multirow[t]{2}{*}{ Anthocerotaceae } & Anthoceros agrestis & 57 & 47 & 0 \\
\hline & Phaeoceros carolinianus & 24 & 14 & 0 \\
\hline Blasiaceae & Blasia pusilla & 4 & 0 & $1(\mathrm{~g})$ \\
\hline Codoniaceae & Fossombronia wondraczekii & 16 & 8 & 0 \\
\hline \multirow[t]{2}{*}{ Pelliaceae } & Pellia endiviifolia & 3 & 0 & 0 \\
\hline & Pellia epiphylla & 1 & 0 & 0 \\
\hline \multirow[t]{6}{*}{ Ricciaceae } & Riccia bifurca & 9 & 4 & 0 \\
\hline & Riccia cavernosa & 13 & 10 & 0 \\
\hline & Riccia ciliata & 17 & 10 & 0 \\
\hline & Riccia glauca & 118 & 94 & 0 \\
\hline & Riccia huebeneriana & 3 & 3 & 0 \\
\hline & Riccia sorocarpa & 64 & 52 & 0 \\
\hline Marchantiaceae & Marchantia polymorpha & 22 & 0 & $17(\mathrm{~g})$ \\
\hline \multirow[t]{6}{*}{ Polytrichaceae } & Atrichum angustatum ${ }^{3 *}$ & 1 & . & . \\
\hline & Atrichum tenellum & 3 & 0 & 0 \\
\hline & Atrichum undulatum & 5 & 0 & 0 \\
\hline & Pogonatum urnigerum ${ }^{1}$ & 1 & . & . \\
\hline & Polytrichum piliferum & 1 & 0 & 0 \\
\hline & Polytrichum juniperinum & 1 & 0 & 0 \\
\hline Encalyptaceae & Encalypta streptocarpa & 1 & 0 & 0 \\
\hline \multirow[t]{4}{*}{ Funariaceae } & Entosthodon fascicularis & 8 & 7 & 0 \\
\hline & Funaria hygrometrica & 44 & 38 & 0 \\
\hline & Physcomitriella patens & 5 & 5 & . \\
\hline & Physcomitrium pyriforme & 38 & 29 & 0 \\
\hline Grimmiaceae & Racomitrium canescens $s^{4 \star}$ & 1 & . & . \\
\hline Archidiaceae & Archidium alternifolium $^{3 *}$ & 1 & . & . \\
\hline \multirow[t]{2}{*}{ Fissidentaceae } & Fissidens taxifolius & 1 & 0 & 0 \\
\hline & Fissidens viridulus & 2 & 1 & 0 \\
\hline \multirow[t]{5}{*}{ Ditrichaceae } & Ceratodon purpureus & 95 & 9 & 0 \\
\hline & Ditrichum heteromallum & 3 & 1 & 0 \\
\hline & Ditrichum pusillum & 7 & 1 & $6(t)$ \\
\hline & Pleuridium subulatum & 18 & 12 & 0 \\
\hline & Trichodon cylindricus & 85 & 4 & $77(\mathrm{t})$ \\
\hline \multirow[t]{6}{*}{ Dicranaceae } & Dicranella cerviculata $^{3 *}$ & 1 & . & . \\
\hline & Dicranella heteromalla ${ }^{3 *}$ & 1 & . & . \\
\hline & Dicranella rufescens & 6 & 4 & 0 \\
\hline & Dicranella schreberiana & 1 & 0 & 0 \\
\hline & Dicranella staphylina & 90 & 0 & $90(\mathrm{t})$ \\
\hline & Dicranella varia & 52 & 18 & $29(\mathrm{t})$ \\
\hline \multirow[t]{18}{*}{ Pottiaceae } & Acaulon muticum & 20 & 12 & 0 \\
\hline & Barbula convoluta & 49 & 2 & $47(t)$ \\
\hline & Barbula unguiculata & 118 & 35 & 0 \\
\hline & Didymodon vinealis & 1 & 0 & 0 \\
\hline & Ephemerum minutissimum & 1 & 1 & 0 \\
\hline & Ephemerum serratum & 26 & 15 & 0 \\
\hline & Microbryum davallianum & 13 & 13 & 0 \\
\hline & Microbryum floerkeanum & 3 & 3 & 0 \\
\hline & Phascum cuspidatum & 135 & 112 & 0 \\
\hline & Protobryum bryoides & 3 & 3 & 0 \\
\hline & Pterygoneurum ovatum & 1 & 1 & 0 \\
\hline & Pterygoneurum subsessile & 1 & 1 & 0 \\
\hline & Tortula lanceolata ${ }^{3 *}$ & 1 & . & . \\
\hline & Tortula modica & 35 & 35 & 0 \\
\hline & Tortula truncata & 113 & 107 & 0 \\
\hline & Weissia brachycarpa & 3 & 3 & 0 \\
\hline & Weissia controversa ${ }^{1}$ & 1 & . & . \\
\hline & Weissia squarrosa & 1 & 1 & 0 \\
\hline
\end{tabular}


Tab. 1 (continued)

\begin{tabular}{|c|c|c|c|c|}
\hline 1 & 2 & 3 & 4 & 5 \\
\hline Meesiaceae & Leptobryum pyriforme & 20 & 1 & $15(\mathrm{t})$ \\
\hline Bartramiaceae & Philonotis caespitosa ${ }^{2}$ & 1 & . & . \\
\hline \multirow[t]{14}{*}{ Bryaceae } & Bryum algovicum ${ }^{3 *}$ & 1 & . & . \\
\hline & Bryum argenteum & 127 & 10 & $6(b)$ \\
\hline & Bryum caespiticium & 61 & 6 & 0 \\
\hline & Bryum capillare & 1 & 0 & 0 \\
\hline & Bryum dichotomum & 6 & 0 & $6(b)$ \\
\hline & Bryum gemmilucens & 2 & 0 & 2 \\
\hline & Bryum klinggraeffii & 54 & 0 & $54(\mathrm{t})$ \\
\hline & Bryum pallens & 1 & 0 & 1 \\
\hline & Bryum pallescens & 1 & 0 & 0 \\
\hline & Bryum rubens & 34 & 0 & $34(\mathrm{t})$ \\
\hline & Bryum ruderale & 3 & 0 & 3 \\
\hline & Bryum subapiculatum & 59 & 0 & $59(\mathrm{t})$ \\
\hline & Bryum violaceum & 29 & 0 & $29(\mathrm{t})$ \\
\hline & Bryum weigelii $^{3 *}$ & 1 & . & . \\
\hline \multirow[t]{8}{*}{ Mielichhoferiaceae } & Pohlia annotina & 2 & 0 & 2(b) \\
\hline & Pohlia bulbifera $^{3 *}$ & 1 & . & . \\
\hline & Pohlia camptotrachela & 7 & 0 & 7 (b) \\
\hline & Pohlia drummondii & 1 & 0 & $1(\mathrm{~b})$ \\
\hline & Pohlia lescuriana & 2 & 2 & 0 \\
\hline & Pohlia melanodon & 4 & 4 & 0 \\
\hline & Pohlia nutans & 1 & 0 & 0 \\
\hline & Pohlia wahlenbergii & 22 & 0 & 0 \\
\hline \multirow[t]{3}{*}{ Plagiomniaceae } & Plagiomnium affine & 1 & 0 & 0 \\
\hline & Plagiomnium elatum & 1 & 0 & 0 \\
\hline & Plagiomnium ellipticum & 1 & 0 & 0 \\
\hline \multirow[t]{4}{*}{ Amblystegiaceae } & Amblystegium serpens & 1 & 0 & 0 \\
\hline & Campyliadelphus chrysophyllus & 3 & 0 & 0 \\
\hline & Campylium stellatum & 3 & 0 & 0 \\
\hline & Leptodictyum riparium & 1 & 0 & 0 \\
\hline Thuidiaceae & Abietinella abietina & 1 & 0 & 0 \\
\hline \multirow[t]{5}{*}{ Brachytheciaceae } & Brachythecium albicans & 15 & 0 & 0 \\
\hline & Brachythecium rutabulum & 16 & 0 & 0 \\
\hline & Brachythecium salebrosum & 65 & 0 & 0 \\
\hline & Brachythecium velutinum & 1 & 0 & 0 \\
\hline & Oxyrrhynchium hians & 113 & 0 & 0 \\
\hline Hylocomiaceae & Rhytidiadelphus squarrosus & 1 & 0 & 0 \\
\hline \multirow[t]{2}{*}{ Hypnaceae } & Calliergonella cuspidata & 3 & 0 & 0 \\
\hline & Hypnum cupressiforme & 1 & 0 & 0 \\
\hline
\end{tabular}

${ }^{1}-[35] ;{ }^{2}-[36] ;{ }^{3}-[34] ;{ }^{4}-[37] ;{ }^{*}-$ no herbarium specimens. $\mathrm{b}$ - bulbils; $\mathrm{g}$ - gemmae; $\mathrm{t}$ - rhizoidal tubers.

Riccia was the most abundant genus of liverworts (6 species). Four dominant genera (Bryum, Dicranella, Pohlia and Riccia) covered $35 \%$ of all registered species, 31 genera were represented by one species.

Dominance of acrocarpous (84.3\%) mosses over pleurocarpous $(15.7 \%)$ was characteristic of morphological forms of the recorded mosses. The ratio of pleurocarpous mosses to acrocarpous was 1:5. Hepatics were represented exceptionally by thalloid forms.

Among the recorded bryophytes sporophytes and specialized asexual propagules (gemmae for hepatics), rhizoidal tubers and bulbils (for mosses) were common (Tab. 1). According to sexuality, 36 species were monoicous, 47 - dioicous and 2 (Acaulon muticum and Fissidens viridulus) - polyoicous.
The presence of reproductive units was significantly different $(C C=0.479, P<0.001)$ between monoicous and dioicous species. Most of species bearing asexual propagules or found without any reproductive units were dioicous. Monoicous species were more common than dioicous among species recorded with sporophytes (64\% and 36\%, accordingly). Significant differences $(P<0.001$, Mann-Whitney $U$ test) were ascertained in the frequency of the occurrence of sporophytes between these two groups of species (Fig. 2).

Based on common records of species and records with sporophytes all species fall into four groups (Fig. 3): the first two groups of different frequency cover rarely sporulating species (up to $50 \%$ of all records), the third and fourth groups - frequently sporulating species (more than $50 \%$ of all records). 


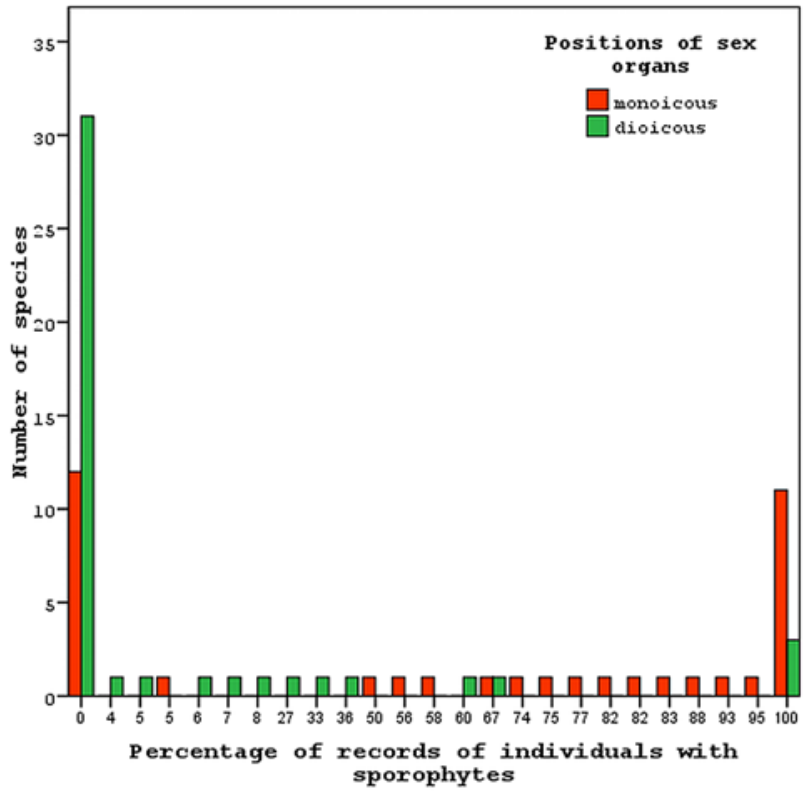

Fig. 2 Numbers of species recorded with certain percentage of sporulating individuals by comparing monoicous and dioicous species.
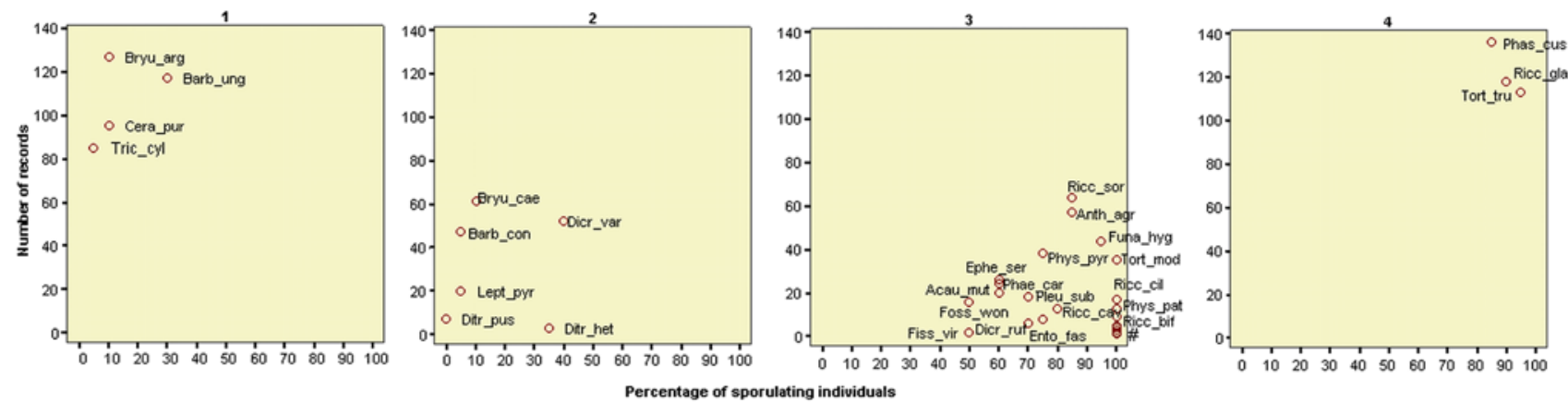

\# Micr_dav Micr_flo Pohl_nnel Pohl_les Prot_bry Pter_ova Pter_su Ricc_hue Weis_bra Weis_squ
The frequency of the occurrence of sporophytes was significantly negatively $(P<0.001$, Kendall's tau-c $=-0.615)$ related with life span of the species. Most of species characterized by high sporophyte production (all species of the fourth group and $75 \%$ of the third group) were of less than one-year life span, whereas most of rarely sporulating species (all of the first group and $83 \%$ of the second group) - of a few-year life span. None of the species of many-year potential life span were recorded with sporophytes.

The bryophytes recorded in arable fields of Lithuania were represented by 10 life-history strategies. The proportion in life-history strategies was significantly different if compared to the whole Lithuanian bryoflora $(P<0.001, C C=0.312)$ and soil inhabiting bryophytes $(P<0.001, C C=0.316)$. Significant increase of the percentage of ephemeral colonists (up to 4.8 times), annual shuttles (up to 3.5 times) and fugitives (up to 3.9 times) and, on the other hand, decrease of perennials (up to 3.2 times) was evident. Colonists were the most similarly distributed in all three groups. The increase in arable fields of short-lived shuttles was not so pronounced as compared to soil inhabiting bryophytes and to whole Lithuanian bryoflora (Fig. 4).

The distribution of species into six frequency groups seemed to be uneven regarding the most abundant group of species with the lowest frequency (53.6\% of all species). Rare (4-19 localities) and quite rare (20-35 localities) species made up

Fig. 3 Four groups of bryophytes in arable fields of Lithuania based on frequency of records and frequency of records with sporophytes.

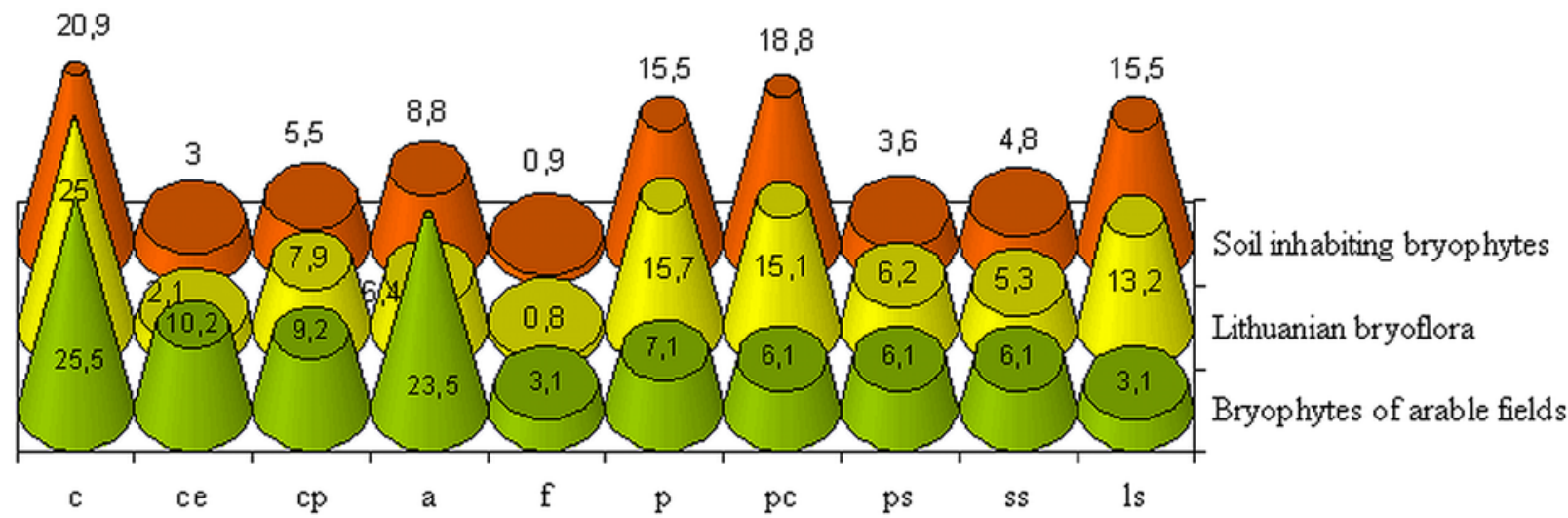

Fig. 4 Comparison of the distribution (percentage) of life-history strategies in bryoflora of arable fields and in overall bryoflora of Lithuania. $\mathrm{a}$ - annual shuttles; $\mathrm{c}$ - colonists; ce - ephemeral colonists; $\mathrm{cp}$ - pioneer colonists; $\mathrm{f}$ - fugitives; ls - long-lived shuttles; $\mathrm{p}$ - perennials; $\mathrm{pc}$ competitive perennials; ps - stress-tolerant perennials; ss - short-lived shuttles. 
additionally $26.5 \%$. We found only nine species to be frequent (44-65 localities), three species very frequent (85-95 localites) and six common (more than 100 localities) in arable fields of Lithuania. (Fig. 5). Bryophyte species of different life span were differently distributed within frequency groups (Kruskal-Wallis test, Chi square $=21.327, d f=5, P<0.01$; Fig. 6). The group of very rare species contained about $21 \%$ of species of less than one-year life span, $67 \%$ of species - a few-year potential life span and $90 \%$ of species - many-year potential life span. Separate life history strategies within frequency groups were differently

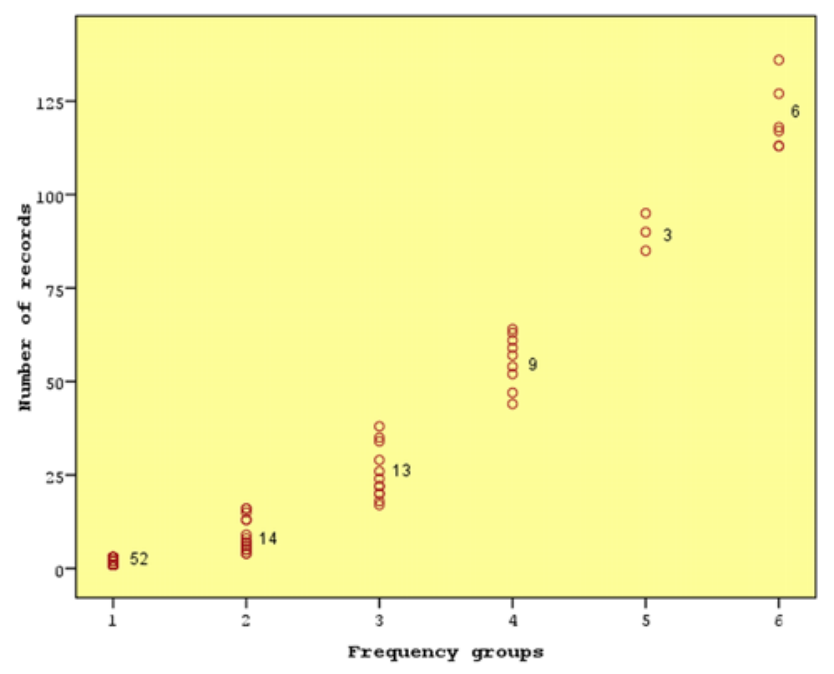

Fig. 5 Frequency groups of bryophyte species recorded in arable fields of Lithuania. Numbers beside the clusters are numbers of species in each frequency group ( 1 - very rare, 2 - rare, 3 - quite rare, 4 - frequent, 5 - very frequent, 6 - common).

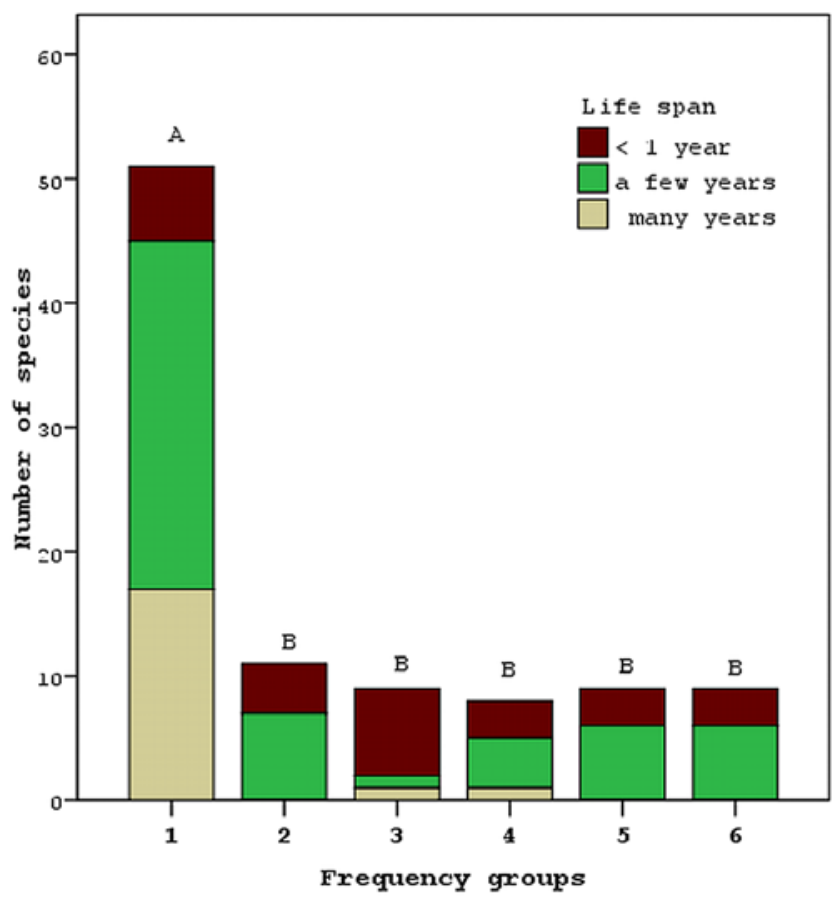

Fig. 6 Proportion of life span groups within frequency groups. Proportion of life spans in group marked with "A" is significantly different from the groups marked with "B". For frequency groups see Fig. 5. presented as well (Kruskal-Wallis test, Chi square $=20.099$, $d f=5, P<0.01)$. The group of very rare species was presented by bryophytes of all life-history strategies, while groups of most frequent species were nearly exceptionally composed by ephemeral colonists, annual shuttles and colonists. Pioneer colonists were quite evenly distributed throughout various frequency groups (Tab. 2).

The most frequent species in arable fields of Lithunia were Phascum cuspidatum, Bryum argenteum, Barbula unguiculata, Riccia glauca, Tortula truncata and Oxyrrhynchium hians.

\section{Comparison of bryoflora of arable fields of Lithuania and other territories of Europe}

The overall number of species registered in arable fields of the other two European territories was smaller (79 species in Slovakia and 89 - in Britain and Ireland). Jaccard's index for bryofloras of arable fields of Lithuania and Slovakia was $47 \%$, while of Lithuania and the British Isles - 36\%. The third (32\%) of bryophytes recorded in arable fields of Lithuania was recorded neither in Slovakia nor in Britain and Ireland. Similar amounts of the species recorded in the British Isles (36\%) and recorded in arable fields of Slovakia (30\%) were not registered in arable fields of Lithuania. Our data harbor 49 species common in arable fields of Britain and Ireland and 56 species common in arable fields of Slovakia. Thirty-nine species are common in all three regions of Europe. Only three species (Lophocolea bidentata var. latifolia, Ephemerum recurvifolium and Microbryum curvicollum were recorded both in the British Isles and Slovakia, but not registered in arable fields of Lithuania.

Species recorded in arable fields only of Lithuania and those recorded in fields of Lithuania, Slovakia and the British Isles were differently presented considering frequency group (Kruskal-Wallis test, Chi square $=38.933, d f=3, P<0.001$ ) and certain life span (Kruskal-Wallis test, Chi square $=18.381$, $d f=3, P<0.001$; Fig. 7). Most species that were not found in arable fields of Slovakia and the British Isles (58.1\%) were very rare in arable fields of Lithuania and to considerable part perennials. Most of species that were recorded in all regions are short-lived species that represent various frequency groups.

\section{Discussion}

\section{General data on bryophyte diversity, mode of reproduction and life-history strategies}

The results of our study confirm that arable land is one of the richest habitats in terricolous bryophytes. Soil disturbances also promote higher vascular plant diversity as compared to undisturbed patches $[47,48]$. The abundance of bryophyte species that occur in arable fields (about $22 \%$ of the country's bryoflora) is lower than in forests and it is similar to that in mires [25]. The structure of bryoflora of this monotonous habitat is specific, reflecting adaptations of bryophytes to frequent disturbances.

Although the bryophytes of arable fields represent considerable part of the country's bryoflora (23\% of the genera and even $43 \%$ of families), most of species are concentrated in few systematic groups. The highly represented families Pottiaceae, Bryaceae, Mielichhoferiaceae and Ricciaceae as well as the genera Bryum, Dicranella, Pohlia and Riccia conjoin species tolerant to frequent disturbances due to suitable combination of reproduction abilities and life-history strategies [2]. Dominance of thalloid liverworts and the tendency of alteration of the ratio 
Tab. 2 Percentage of distribution of species with certain life-history strategy across frequency groups.

\section{Frequency groups}

\begin{tabular}{|c|c|c|c|c|c|c|}
\hline \multirow[b]{2}{*}{ Life history strategies } & \\
\hline & Very rare & Rare & Quite frequent & Frequent & Very frequent & Common \\
\hline Fugitives & 0 & 0 & 22.2 & 0 & 11.1 & 0 \\
\hline Annual shuttles & 11.8 & 36.4 & 55.6 & 37.5 & 22.2 & 33.3 \\
\hline Colonists & 27.5 & 27.3 & 0 & 12.5 & 22.2 & 44.4 \\
\hline Pioneer colonists & 9.8 & 9.1 & 11.1 & 0 & 11.1 & 11.1 \\
\hline Ephemeral colonists & 3.9 & 9.1 & 0 & 37.5 & 33.3 & 11.1 \\
\hline Short-lived shuttles & 7.8 & 18.2 & 0 & 0 & 0 & 0 \\
\hline Perennials & 11.8 & 0 & 11.1 & 0 & 0 & 0 \\
\hline Competitive perennials & 9.8 & 0 & 0 & 12.5 & 0 & 0 \\
\hline Long-lived shuttles & 5.9 & 0 & 0 & 0 & 0 & 0 \\
\hline Stress-tolerant perennials & 11.8 & 0 & 0 & 0 & 0 & 0 \\
\hline Total & 100 & 100 & 100 & 100 & 100 & 100 \\
\hline
\end{tabular}

towards the increase of acrocarpous mosses are observed in other habitats strongly changed by man $[49,50]$.

Our results support the assumption that bryophytes of disturbed land produce an abundance and variety of sexual and asexual propagules $[2,4]$. Only $23 \%$ of species recorded in arable fields of Lithuania were without any units of reproduction.

Dominance of monoicous species is a specific feature of bryophytes inhabiting arable fields; the Lithuanian data show opposite results - dominance of dioicous species [41]. The analysis of British bryophyte flora revealed that dioicous species sporulate more rarely than monoicous $[51,52]$. The same tendency was observed in our study. Moreover, among sporulating species sporophytes occurred more frequently in monoicous than in dioicous species (Fig. 2). As it has been highlighted by Longton and Shuster [53] and by Longton [54], frequent spatial separation of the sexes in dioicous species may limit or even render impossible production of spores. Reproduction success of the majority of dioicous species is determined by specialized asexual propagules [26].

So, the large proportion of ephemeral colonists and annual shuttles, i.e. species of short life span, but high investment in sexual or asexual reproduction in total bryoflora of arable fields
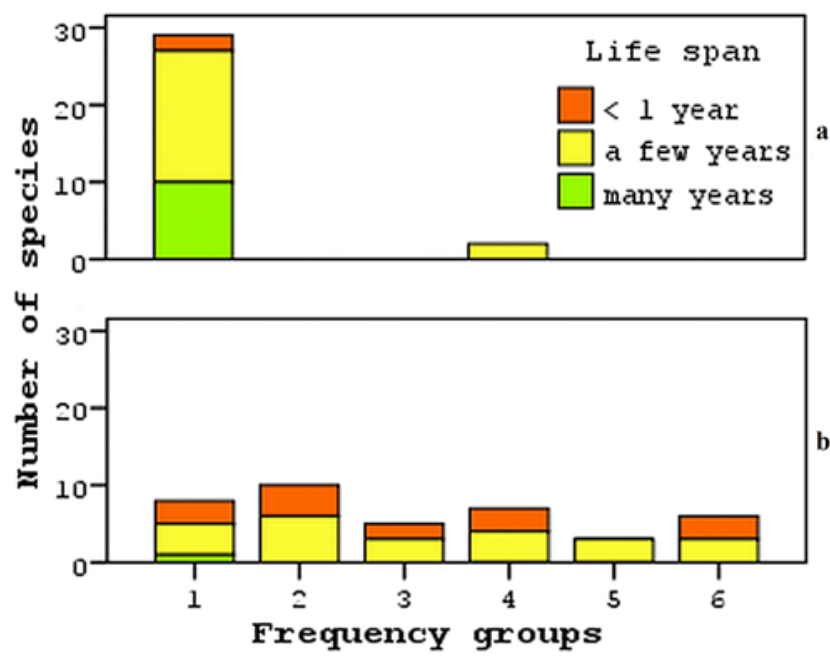

Fig. 7 Numbers of species of different life spans in the six frequency groups by comparing bryophytes recorded in arable land of Lithuania only (a) and Lithuania, Slovakia and the British Isles (b). For frequency groups see Fig. 5.
(Fig. 4) and among frequent species of the habitat (Tab. 2) has no accidental character. Namely, species of these life traits produce large spores and rhizoidal tubers which are able to survive for along time in diaspore bank [3]. Similar adaptations are characteristic of bryophytes occupying other habitats with disturbed cover of vegetation [38,51,55-57]. Pioneer colonists, who often produce bulbils, unlike ephemeral colonists were not so widespread in the studied habitat. Colonists, which do not show preference to arable land (Fig. 4), due to their wide distribution make also the largest part among common bryophytes in arable fields of Lithuania. As it has been pointed in various studies $[17,38,58,59]$, perennials of long life span, high investment in gametophyte growth and minor production of reproductive units are more competitive in stable habitats.

The results of the investigations supplemented the knowledge about the frequency of some bryophyte species in the country and adjacent areas. It was discovered that species (e.g. Dicranella staphylina, Bryum klinggraeffi, B. violaceum, B. rubens, Ditrichum pusillum, Trichodon cylindricus) earlier considered to be rare or not recorded in Lithuania and other Baltic countries [60] occurred to be quite widely distributed throughout the territory. Nevertheless, the most of the recorded species were very rare (1-3 records). Regional reasons for rarity and differences in species diversity are complex. They can be caused by local climate in the present and past, geographical and ecological conditions as well as historical and present land use [61]. On the habitat scale, the nature of the habitat is an additional reason causing distribution pattern of species. Frequent disturbances in arable land determine the rarity of species of long life span. Perennial species have been ascertained to be rare in arable fields of Lithuania. Studies in stubble fields of Poland show them to be rare as well $[11,14]$. Opposite results have been obtained while analyzing rare bryophyte species of the Lithuanian bryoflora and of the three Baltic countries - on regional scale rare species of short life span prevail [61]. Söderström and During [62] have ascertained that among mosses that are rare world-wide, shortlife-span species are the most abundant. Species rarity of some bryophytes in arable land of Lithuania can be determined by their common geographical distribution pattern. For example, the main ranges of Bryum gemmilucens, Pterygoneurum subsessile and Riccia huebeneriana are in southern temperate regions $[39,63]$, therefore, in the hemiboreal region, which crosses the territory of Lithuania, they are rare. Distribution of species with special ecological requirements is usually restricted by the 
number of suitable habitats. For instance, it seems likely that the shortage of base-rich soils in Lithuania is the reason of the rarity of basiphilous species such as Microbryum floerkeanum, Protobryum bryoides, Pterygoneurum ovatum, P. subsessile and Tortula lanceolata. Low use of acid soils for agriculture or liming of acid arable land [32] determines the rarity of acidophytes (e.g. Atrichum angustatum and Riccia huebeneriana). Distribution of Riccia huebeneriana in arable fields of Lithuania is additionally limited by its special ecological requirement, i.e. sites of a constant, relatively high moisture content of the substrate [63]. Finally, subjective reasons, e.g. deficiency of propagules or sporophytes (important in identification) may be significant for such minute plants as bryophytes. Commonly, as in case of Riccia huebeneriana or Pterygoneurum subsessile, distribution pattern of the species is determined by a complexity of factors.

\section{Bryophytes of arable fields of Lithuania and other regions of Europe}

We have not ascertained regionally specific species on the studied habitats. Most of species that were not found in Slovakia, Britain and Ireland, but recorded in Lithuania, are perennials (Fig. 7), which are common in other habitats of Lithuania, but uncommon in arable land (e.g. Abietinella abietina, Homalothecium lutescens, Hypnum cupressiforme, Racomitrium canescens, etc). Their occurrence in arable land is determined by local landscape traits. On the contrary, short-lived species well adapted to specificity of the habitat, i.e. frequent and regular disturbances regardless their frequency are shared between all three countries. We find the distinctions determined mainly by climate and soil characteristics of the regions while analyzing species recorded not in Lithuania. More species of the southern distribution (e.g. Fossombronia caespitiformis, Pleuridium acuminatum, Bryum demaretianum, Ephemerum cohaerens, Didymodon spadiceus) and more basiphilous species (e.g. Aloina rigida, Didymodon vinealis, Microbryum curvicollum, M. starckeanum, M. rectum) were registered in arable fields of both Slovakia and British Isles compared to Lithuania. As it was mentioned earlier, basiphilous species and bryophytes of more southern distribution make significant part of species that are rare in arable fields of Lithuania. None of the mentioned species were recorded in arable fields close to Lithuania, e.g. Poland $[9-12,14]$. The species favored by oceanic climate, such as Anthoceros punctatus, Phaeoceros laevis, Bryum gemmiferum, B. riparium, Didymodon tomaculosus, Weissia xmittenii, Ephemerum stellatum, make an additional distinctive part of bryoflora in the cultivated land of Britain and Ireland. Moss Leptophascum leptophyllum and liverwort Riccia crystallina are regarded as introduced in the British Isles [2]. These species were not recorded in Lithuania and Slovakia. A high number of alien species distinguishes United Kingdom in Europe [64]. Similar results, which mark the importance of climate or soil variables in different geographical regions, have been reported in the studies on weed vegetation [19].

Apropos of, in arable fields of Lithuania, we found $90 \%$ of species from the preliminary list of bryophytes presented by Whitehouse for Quebec (Canada) [21]. The differences are accounted for five species; two of these are of non-European distribution.

Changes in the lists of all countries will inevitably follow further investigations. According to Porley [2], changes can occur due to species previously overlooked, new to science or thought to be geographically restricted. However, the main tendencies of distinctions, especially those caused by climatic and edaphic peculiarities of the regions should remain.

\section{Acknowledgments}

The study is a part of log-term program of Nature Research Centre "Biological diversity investigations and projections under conditions of global change and anthropogenic effect". The authors are indebted to anonymous reviewers for valuable comments and suggestions on the manuscript.

\section{Authors' contributions}

The following declarations about authors' contributions to the research have been made: data collection, species identification, literature search, database, figures and tables: DA; study design, checking of identified species, data analysis, data interpretation, writing: IJ.

\section{References}

1. Lososova Z, Chytry M, Kuhn I, Hajek O, Horakova V, Pysek P, et al. Patterns of plant traits in annual vegetation of man-made habitats in central Europe. Perspect Plant Ecol Evol Syst. 2006;8(2):69-81. http://dx.doi. org/10.1016/j.ppees.2006.07.001

2. Porley RD. Bryophytes of arable fields: current state of knowledge and conservation. Bull Brit Bryol Soc. 2001;77:50-62.

3. During HJ, Ter Horst B. The diaspore bank of bryophytes and ferns in chalk grassland. Lindbergia. 1983;9(1):57-64.

4. Bisang I. Quantitative analysis of the diaspore banks of bryophytes and ferns in cultivated fields in Switzerland. Lindbergia. 1996;21:9-20.

5. Schofield WB. Introduction to bryology. New York NY: Macmillan; 1985.

6. Risse S. Rhizoid gemmae in mosses. Lindbergia. 1987;13(3):111-126.

7. Herben T. The role of reproduction for persistence of bryophyte populations in transient and stable habitats. J Hattori Bot Lab. 1994;76:115-126.

8. European Committee for Conservation of Bryophytes. Red data book of European bryophytes. Trondheim: European Committee for Conservation of Bryophytes; 1995.

9. Jędrzejko K. Mchy (Bryopsida) Górnośląskiego Okręgu Przemysłowego i Leśnego Pasa Ochronnego wobec antropopresji. Wrocław: National Ossoliński Institute; 1990. (Prace i studia / Polska Akademia Nauk, Instytut Podstaw Inżynierii Środowiska).

10. Fudali E. Species diversity and special distribution of bryophytes in urban areas - a case study of the city of Szczecin. Fragm Flor Geobot. 1994;39(2):563-573.

11. Fojcik B. Mchy siedlisk antropogenicznych na Wyżynie Wieluńskiej. Acta Biol Sil. 1998;33(50):143-160.

12. Fojcik B, Stebel A. Preliminary studies on the bryoflora of Katowice town (Silesian Upland, Southern Poland). Fragm Flor Geobot. 1999;44(1):129-140.

13. Fukarek C. Die Verbreitung der Ackermoose im Raum Wuppertal (Nordrhein-Westfalen). Herzogia. 1998;13:81-88.

14. Kola W, Turzańska M. Zbiorowiska mszaków pól uprawnych Dolnego Śląska. I. Acta Universitatis Wratislaviensis. Prace Botaniczne. 1993;53:3-12.

15. Zechmeister HG, Tribsch A, Moser D, Peterseil J, Wrbka T. Biodiversity "hot spots" for bryophytes in landscapes dominated by agriculture in Austria. Agric Ecosyst Environ. 2003;94(2):159-167. http://dx.doi.org/10.1016/ S0167-8809(02)00028-2

16. Sauberer N. Surrogate taxa for biodiversity in agricultural landscapes of eastern Austria. Biol Conserv. 2004;117(2):181-190. http://dx.doi. org/10.1016/S0006-3207(03)00291-X

17. Zechmeister HG, Moser D. The influence of agricultural land-use intensity on bryophyte species richness. Biodivers Conserv. 2001;10:1609-1625.

18. Zechmeister H, Tribsch A, Moser D, Wrbka T. Distribution of 
endangered bryophytes in Austrian agricultural landscapes. Biol Conserv. 2002;103(2):173-182. http://dx.doi.org/10.1016/S0006-3207(01)00119-7

19. Lososová Z, Chytrý M, Cimalová S, Kropáč Z, Otýpková Z, Pyšek P, et al. Weed vegetation of arable land in Central Europe: gradients of diversity and species composition. J Veg Sci. 2004;15(3):415-422. http://dx.doi. org/10.1111/j.1654-1103.2004.tb02279.x

20. Porley R. Arable bryophytes: a field guide to the mosses, liverworts and hornworts of cultivated land in Britain and Ireland. Maidenhead: WILDGuides; 2006.

21. Whitehouse HLK. Bryophytes of arable fields in Quebec and Slovakia, including new records of Bryum demaretianum Arts. Lindbergia. 2001;26(1):29-32.

22. Kresáňová K, Mišíková-Janovicová K, Kubinská A. Diversity of bryophytes in agro-coenoses of Slovakia. Biologia. 2005;60(1):9-15.

23. Andriušaityte D. Riccia ciliata Hoffm. - nauja kerpsamanių rūšis Lietuvoje. Botanica Lithuanica. 2001;7(2):209-212.

24. Andriušaityte $\mathrm{D}$. New to Lithuanian bryoflora species recorded from arable fields. Botanica Lithuanica. 2002;8(3):203-214.

25. Jukoniene $\mathrm{I}$. The impact of anthropogenic habitats for distribution of rare bryophyte species in Lithuania. Folia Cryptog Estonica. 2008;44:55-62.

26. Andriušaityte $\mathrm{D}$, Jukonienė $\mathrm{I}$. Mosses with vegetative propagules in arable fields of Lithuania. Acta biologica Universitatis Daugavpiliensis. 2010;suppl(2):121-132.

27. Kudaba Č. Lietuvos aukštumos. Vilnius: Mokslas; 1983.

28. Statistikos Departamentas. Lietuvos statistikos metraštis. Vilnius: Statistikos Departamentas; 2010.

29. Kavaliauskas P, Baškytè R. Kraštovaizdžio apsauga. In: Jankevičius K, Stasinas J, editors. Lietuvos aplinkosaugos raida. Vilnius: Ministry of Environment of the Republic of Lithuania; 2000. p. 247-251.

30. Bukantis A. Dirvodaros veiksniai. Klimatas. In: Liekis A, editor. Lietuvos dirvožemiai. Vilnius: Mokslas; 2001. p. 120-131.

31. Mažvila J, editor. Lietuvos dirvožemių agrocheminès savybės ir jų kaita. Kaunas: Lietuvos žemdirbystès institutas; 1998.

32. Mažvila J, Adomaitis T, Eitminavičius L. Lietuvos dirvožemių rūgštumo pokyčiai jų nebekalkinant. Žemdirbystė. 2004;88(4):3-20.

33. Statistikos Departamentas prie Lietuvos Respublikos Vyriausybès [Internet]. 2010 [cited 2010 Apr 19]; Available from: http://www.stat.gov.lt/ uploads/1074153180_ZU_sur.pdf

34. Stancevičius A. Lietuvos pasèlių augalijos geobotaniniai tyrimai. Lietuvos Žemès Ükio Akademijos Mokslo darbai. 1959;6(1):3-149.

35. Minkevičius A. Pradmenys Lietuvos samanų florai tirti. I dalis. Vytauto Didžiojo Universiteto Matematikos-Gamtos fakulteto Darbai. 1931;5(2):296-325.

36. Minkevičius A. Pradmenys Lietuvos samanų florai tirti. II dalis. Vytauto Didžiojo Universiteto Matematikos-Gamtos fakulteto Darbai. 1935;9:163-179.

37. Bakšytè I. Kai kurių Alytaus vietovių samanų flora. Lietuvos TSR aukštujjų mokyklų mokslo darbai. 1968;8:149-156.

38. During HJ. Ecological classification of bryophytes and lichens. In: Bates JW, Farmer AM, editors. Bryophytes and lichens in changing environment. Oxford: Clarendon Press; 1992. p. 1-31.

39. Dierßen K. Distribution, ecological amplitude and phytosociological characterization of European bryophytes. Berlin: Cramer in der Gebrüder Borntraeger Verlagsbuchhandlung; 2001. (Bryophytorum Bibliotheca; vol 56).

40. Jukonienė I. Lietuvos kiminai ir žaliosios samanos (Mosses of Lithuania). Vilnius: Botanikos instituto leidykla; 2003.

41. Jukonienè I. Current state of knowledge on the bryophyte flora of Lithuania. Botanica Lithuanica. 2010;16(1):22-32.
42. Naujalis J, Kalinauskaitè N, Grinevičienė M. Vadovas Lietuvos kerpsamanèms pažinti. Vilnius: Žodynas; 1995.

43. Jäger EJ, Welk E. Pflanzengeographische Gliederung Europas. In: Bohn U, Neuhäussl R, Gollub G, Hettwer C, Neuhäusslová Z, Schlüter H, et al., editors. Karte der natürlichen Vegetationen Europas. Bonn: Federal Agency for Nature Concervation; 2004. p. 79-86.

44. Magurran AE. Measuring biological diversity. Oxford: Blackwell; 2004.

45. Grolle R, Long DG. An annotated checklist of the Hepaticae and Anthocerotae of Europe and Macaronesia. J Bryol. 2000;22:103-140.

46. Hill MO, Bell N, Bruggeman-Nannenga MA, Brugués M, Cano MJ, Enroth J, et al. An annotated checklist of the mosses of Europe and Macaronesia. J Bryol. 2006;28(3):198-267. http://dx.doi.org/10.1179/174328206X119998

47. Korzeniak J. Species richness and diversity related to anthropogenic soil disturbance in abandoned meadows in the Bieszczady Mts. (Eastern Carpathians). Acta Soc Bot Pol. 2005;74(1):65-71.

48. Schnoor TK, Olsson PA. Effects of soil disturbance on plant diversity of calcareous grasslands. Agric Ecosyst Environ. 2010;139(4):714-719. http:// dx.doi.org/10.1016/j.agee.2010.10.018

49. Żarnowiec J. The bryoflora of urban areas - a floristical-ecological case study of Oświęcim town (S Poland). Fragm Flor Geobot. 1996;41:355-377.

50. Isermann M. Diversity of bryophytes in an urban area of NW Germany. Lindbergia. 2007;32(3):75-81.

51. Longton RE. Reproductive biology and life-history strategies. Adv Bryol. 1997;6:65-107.

52. Laaka-Lindberg S, Hedderson TA, Longton RE. Rarity and reproductive characters in the British hepatic flora. Lindbergia. 2000;25:78-84.

53. Longton RE, Shuster RM. Reproductive biology. In: Schuster RM, editor. The new manual of bryology. Nichinan: Hattori Botanical Laboratory; 1983. p. 386-462. (vol 1).

54. Longton RE. The role of bryophytes and lichens in terrestrial ecosystems. In: Bates JW, Farmer AM, editors. Bryophytes and lichens in changing environment. Oxford: Clarendon Press; 1992. p. 32-76.

55. Palisaar J, Poschlod P. Bryophyte diversity in cleared and uncleared windthrow gaps and the adjacent forest stands in the Bavarian Forest National Park, SE Germany. Lindbergia. 2001;26:46-54.

56. Kimmerer RW. Patterns of dispersal and establishment of bryophytes colonizing natural and experimental treefall mounds in northern hardwood forests. Bryologist. 2005;108(3):391-401. http://dx.doi. org/10.1639/0007-2745(2005)108[0391:PODAEO]2.0.CO;2

57. Giudice RL, Mazimpaka V, Lara F. The urban bryophyte flora of the city of Enna (Sicily, Italy). Nova Hedwigia. 1997;64(1-2):249-266.

58. During HJ, Tooren BF. Viable plant diaspores in the guts of earth worms. Acta Bot Neerl. 1988;37:181-185.

59. Longton RE. Adaptations and strategies of polar bryophytes. Bot J Linn Soc. 1988;98(3):253-268. http://dx.doi.org/10.1111/j.1095-8339.1988.tb02429.x

60. Söderström L, editor. Preliminary distribution maps of bryophytes in northwestern Europe. Trondheim: Mossornas Vänner; 1996. (vol 2).

61. Vellak K, Vellak A, Ingerpuu N. Reasons for moss rarity: study in three neighbouring countries. Biol Conserv. 2007;135(3):360-368. http://dx.doi. org/10.1016/j.biocon.2006.10.009

62. Söderström L, During HJ. Bryophyte rarity viewed from the perspectives of life history strategy and metapopulation dynamics. J Bryol. 2005;27(3):261-268. http://dx.doi.org/10.1179/174328205X70010

63. Damsholt K. Illustrated flora of Nordic liverworts and hornworts. Lund: Nordic Bryological Society; 2002.

64. Drake JA., editor. Handbook of alien species in Europe. Dordrecht: Springer; 2009. (Invading nature - Springer series in invasion ecology; vol 3). 